\title{
A NEW APPROACH IN APPLICATION AND DESIGN OF TOROIDAL AXIAL-FLUX PERMANENT MAGNET OPEN-SLOTTED NN TYPE (TAFPMOS-NN) MOTOR
}

\author{
Engin Hüner, Mustafa Caner Aküner, Ŭğur Demir
}

Original scientific paper

This paper presents a novel approach in design of toroidal axial flux permanent magnet open-slotted NN type (TAFPMOS-NN) motor. TAFPMOS-NN motor is an accomplished both theoretical and experimental model. The results of theoretical works and experimental works are performed. TAFPMOS$\mathrm{NN}$ has open-slotted structure and the winding on the core surface which are the most important properties of TAFPMOS-NN motor. This situation has created the hybrid structure electric machine by combining toroidal winding without open-slotted motor properties and toroidal winding with open-slotted motor properties. The mentioned motor types have a problem such as cogging torque. The cogging problem is resolved greatly by the proposed method so that high torque, efficiency and cost saving for TAFPMOS-NN type motor are acquired.

Keywords: finite element analysis; optimization; toroidal axial flux permanent magnet open-slotted NN type motor

\section{Novi pristup u primjeni i projektiranju NN tipa motora otvorenih utora s permanentnim magnetima prstenastog aksijalnog toka (TAFPMOS-NN)}

Izvorni znanstveni članak Ovaj rad predstavlja novi pristup u konstrukciji motora NN tipa otvorenih utora s permanentnim magnetima prstenastog aksijalnog toka (TAFPMOS-NN). TAFPMOS-NN motor ostvarenje je i teorijskog i eksperimentalnog modela. Provjereni su rezultati teorijskih i eksperimentalnih radova. TAFPMOS-NN je konstruiran s otvorenim utorima i namotima na površini jezgre što su najvažnija svojstva TAFPMOS-NN motora. Stvoren je električni stroj hibridne strukture s kombinacijom prstenastih namota bez karakteristika motora s otvorenim utorima i prstenastih namota s karakteristikama motora s otvorenim utorima. Navedene vrste motora imaju problem zakretnog momenta zupčanika (cogging torque). Predložena metoda rješava taj problem, pa je postignuta učinkovitost i smanjenje troškova za TAFPMOS-NN tip motora.

Ključne riječi: metoda konačnih elemenata; NN tip motora otvorenih utora s permanentnim magnetima prstenastog aksijalnog toka; optimizacija

\section{Introduction}

In recent years, the studies over the permanent magnet machines have increased by evolving neodymium magnet. At the same time, the investigations on axial flux machine have increased. The advantages of the permanent magnet machines are high efficiency, high torque, high power density, and compact structure $[1,2]$. The axial flux machines are manufactured as multi pole due to the axial flux machine structure. Therefore, the axial flux machine has taken place wherever is needed to directdrive property [3]. The axial flux machine has been preferred in the electrical vehicle by the compact structure $[4 \div 8]$

The most studied topic in the axial flux permanent magnet motors is the cogging torque. The cogging torque is interaction between the permanent magnets and the core slots. Cogging torque phenomena is a well-known disadvantage of the motors and affects the applications requiring precision torque control. In literature many authors handled this problem and presented valuable works. Among the literature review the methods including permanent magnet motors are more common and help to reduce the manufacturing costs. These methods cover various slot types of the analyzed permanent magnet motors. Moreover, several authors proposed different magnet geometries to reduce the effect of cogging torque $[9,10]$. Besides, the use of axial flux machines is another application to mitigate the negative effects of cogging torque. The magnetic flux generated in axial flux machine depends on the velocity of the machine. However, this cannot be easily achieved due to the constant excitation flux. Therefore, many methods have recently been presented to increase or decrease magnetic flux.
Parviainen and colleagues presented a new magnet geometry to produce sinusoidal in shape back EMF (Electro Motor Force) and to reduce the effect of cogging torque in 2001. The presented method has been proved by 3D simulations. One of the drawbacks of the previously presented method by Parviainen and colleagues are the reducing of the magnet sizes [11]. Marignetti and colleagues used wound windings in open-slot stator structure in 2005 .

The main advantage of this method is to have more slots even in smaller stator structures while decreasing losses [12].

Park and colleagues demonstrated that axial flux motor without core had a better performance than that of with core in terms of high speed and low torque in 2006 [2].

Rahim and colleagues studied on the axial flux nonslotted direct-drive motor for the use of electric vehicle in 2007. They reported that the new motor type was suitable for electric vehicles with a high performance [13].

Choi and colleagues studied on the effect of cogging torque modelling and analyzing skew in stator in 2009. They proposed new stator geometry with open-slot structure to reduce the effect of cogging torque [14].

Hsu and colleagues achieved to have polarization at the soft magnetic region in rotor inserting additional winding in 1998. The new soft magnetic material was used for changing current direction and strength inside additional winding. One reported disadvantage of this method is that the polarization at the soft magnetic region is exposed to reverse magnetic fields [15].

Tapia and colleagues studied on the variation of rotor flux changing the magnet and iron structure in 2006. The method proved that there was no demagnetization risk 
inside the machine requiring larger magnetic core that was almost a disadvantage of it [16].

Gozalez and colleagues designed a new axial flux machine that was capable of field reducing and tested in 2008. The proposed reducing technique was based on the flux of armature reaction by controlling $d$ axis current. The vector control method was applied to control the flux of air gap. So, the implementation of negative $d$ axis flux is possible. But this method leads to effect of reverse magnetic on the permanent magnets. The soft magnetic region was created by this new design. So, the soft magnetic regions provide occurring low reluctance regions. Therefore, the magnets are outside the reverse magnetic domains [17].

Prufoma and colleagues accomplished the axial flux motor with inner permanent magnet which was made by soft magnetic material. There are two important points in the Prufoma and colleagues study. The first of them is related to distance between the permanent magnets that affects the performance of motor. The second is related to locations of permanent magnets that provides reducing flux technique [18].

In this study, a new TAFPMOS-NN type motor was designed. The designed TAFPMOS-NN type motor has hybrid structure in terms of structure of slot and winding. At the same time, TAFPMOS-NN type motor has wound windings over open-slot and wound windings out of slot. The structure especially shows 3 different axial flux permanent magnet motor properties. The structure of the windings has a shape of multilayer installation. The performance of TAFPMOS-NN motor with a single layer winding is higher than TAFPM (toroidal axial flux permanent magnet) motor [19]. Moreover, its performance is also higher than that of TAFPM with multilayer winding [20]. At the same time, the cogging torque occurring from open-slotted axial flux permanent magnet motors was decreased by increasing air gap in wound windings out of slot. But, increasing the air gap leads to the performance losses. The performance losses in axial flux permanent magnet type motors without the core are decreased by configuration of the winding. Besides, the open-slotted structure provides costreduction in the axial flux permanent magnet motor. As TAFPMOS-NN type motors in comparison with the same type motors have more windings, TAFPMOS-NN type motors do not have overheating problem.

\section{The mechanical dimensions of the toroidal axial flux motor}

The structure of designed toroidal axial flux permanent magnet NN type (TAFPM-NN) motor consists of two rotors and one stator. The stator winding was wound toroidally. Especially, using the permanent magnets which have shape of rectangle provided cost saving for application of TAFPM-NN type motor. 3D model of the designed TAFPM-NN type motor is shown in Fig. 1. This model has flexible-structure, because TAFPM-NN type motor was designed in order to allow to experiment in different rotor and stator structure combination in laboratory conditions.

Mechanical parameter of the designed TAFPM-NN type motor is shown in Tab. 1.

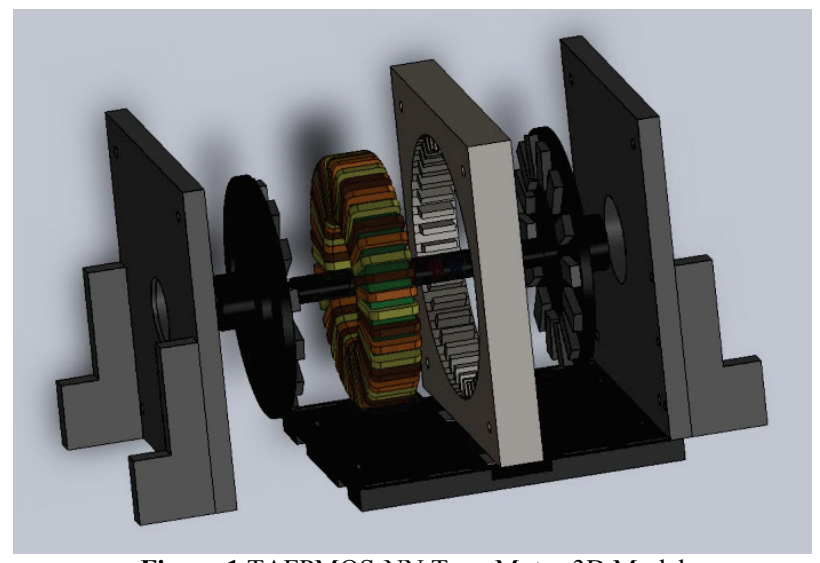

Figure 1 TAFPMOS-NN Type Motor 3D Model

Table 1 TAFPM-NN Type Motor Mechanical Parameters

\begin{tabular}{|l|c|l|r|}
\hline \multicolumn{2}{|c|}{ Stator Dimensions } & \multicolumn{2}{c|}{ Winding } \\
\hline Outer Diameter & $210 \mathrm{~mm}$ & Phase Number & 3 \\
\hline Inner Diameter & $130 \mathrm{~mm}$ & Winding Number & 42 \\
\hline Core Thickness & $40 \mathrm{~mm}$ & Winding Thick. & $15 \mathrm{~mm}$ \\
\hline \multicolumn{1}{|c|}{ NdFeB Magnet Dimensions } & \multicolumn{2}{c|}{ Rotor } \\
\hline Length & $40 \mathrm{~mm}$ & Thickness & $5 \mathrm{~mm}$ \\
\hline Width & $20 \mathrm{~mm}$ & Pole Number & 14 \\
\hline Thickness & $10 \mathrm{~mm}$ & Diameter & $230 \mathrm{~mm}$ \\
\hline
\end{tabular}

\section{The magnetic analysis of the designed motor}

In air gap, the magnetic flux change of the designed toroidal axial flux permanent magnet NN type (TAFPM$\mathrm{NN}$ ) motor was made by using 3D finite element analysis program. The magnetic field change of the designed system is shown in Fig. 2. This system was analyzed along the line placed in air gap.

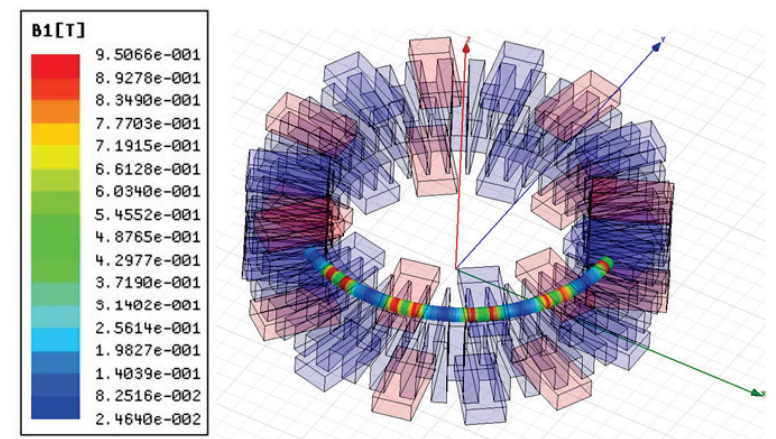

Figure 2 The Magnetic Analysis of TAFPMOS-NN Type Motor [21]

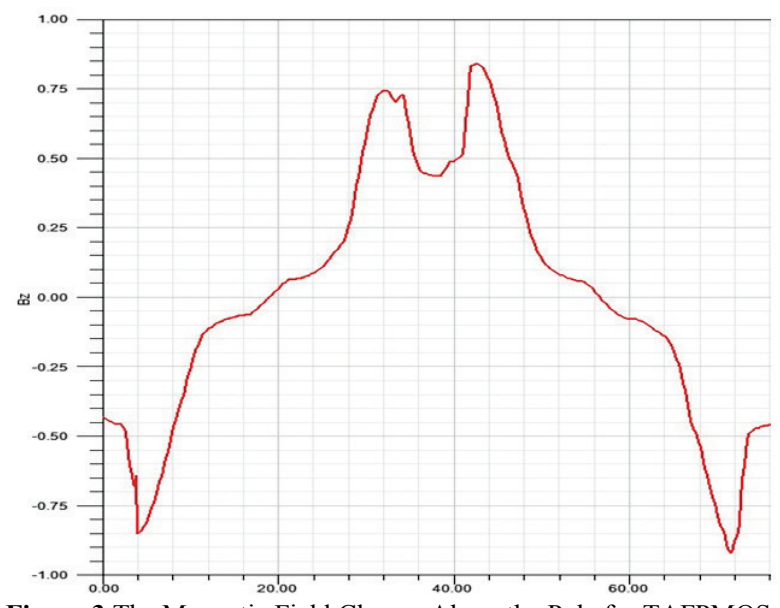

Figure 3 The Magnetic Field Change Along the Pole for TAFPMOSNN Type Motor [21] 
The magnetic field change for a pole along the line is shown in Fig. 3. Inside the pole, Magnetic field value is mean 0,6 Tesla. The value is enough magnetic field value for the electric machine design $[12,22,23]$.

\section{The application of designed model}

The designed TAFPM-NN motor consisting of rectangular permanent magnets is shown in Fig. 4. The production cost of TAFPM-NN motor was decreased significantly by using the rectangular permanent magnet type. Also, width of the slots and magnet number were selected optimally in order to provide precision EMF (Electro Motor Force). In the contrast, permanent magnet shape was changed in the former studies so as to obtain precision EMF. TAFPM-NN motor uses rectangular in shape permanent magnets with the optimal installation and presents a low-cost solution.

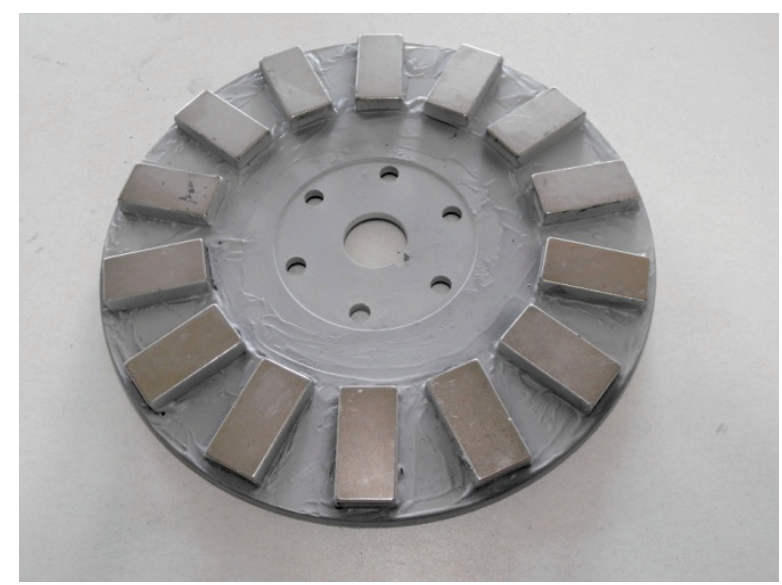

Figure 4 The Rotor Structure of TAFPMOS-NN Type Motor [21]

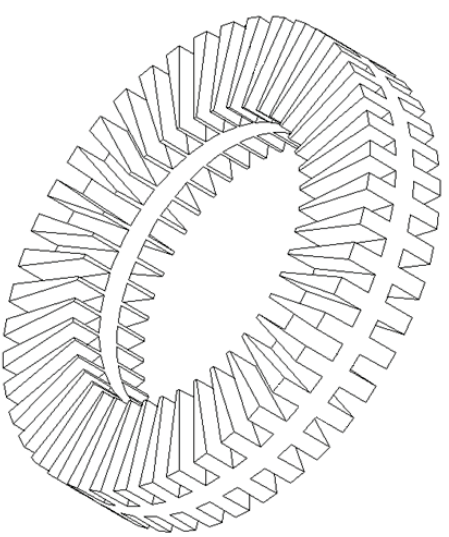

Figure 5 The Stator Structure of TAFPMOS-NN Type Motor [24]

The designed TAFPM-NN motor having open-slotted structure is shown in Fig. 5. Previous studies mentioned high cost production of the stator [4]. The stator core is manufactured easily by using the open-slotted structure. So the production cost of stator was decreased.

The winding section in the slot of the designed TAFPM-NN motor is shown in Fig. 6. Because the volume of the hybrid structure is greater than the other structure, the Winding capacity of the hybrid structure is higher than the other structure.

According to Fig. 5 and Fig. 6, the stator of the designed TAFPM-NN motor is shown in Fig. 7. While the laminated core was insulated by epoxy, the stator winding was wound toroidally.

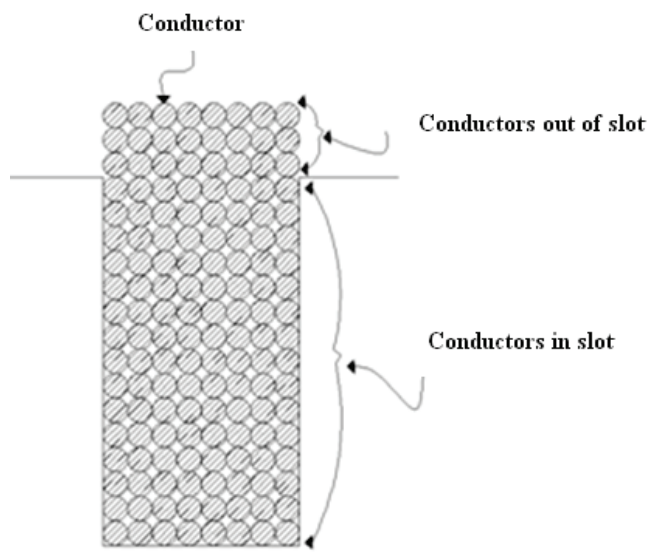

Figure 6 The Slot Structure of Stator [24]

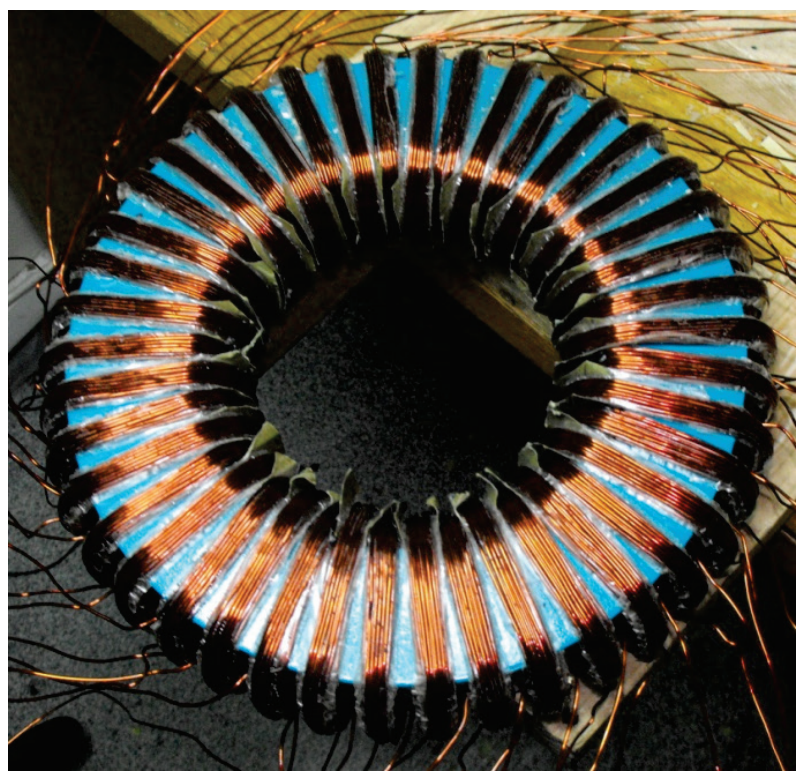

Figure 7 The State of The Laminated Stator Placed Winding [21]

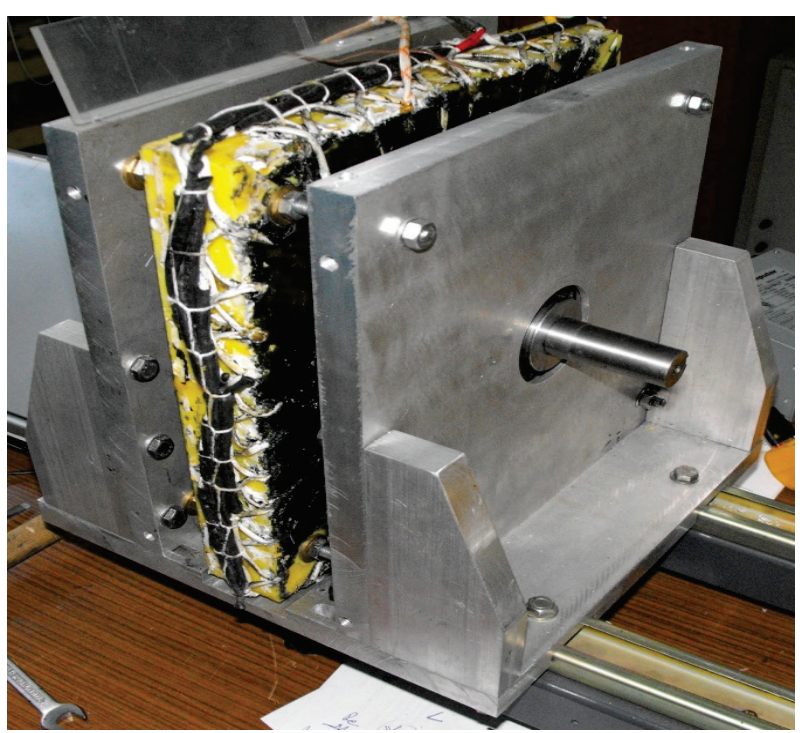

Figure 8 The System Setup of TAFPMOS-NN Type Motor [21]

The rotor and the stator of designed TAFPM-NN motor are shown in Fig. 8. The different rotor and stator types combination was applied and experienced by the design. 


\section{The result of experiment}

The experiments were performed in the system shown in Fig. 8. The measurement device used in experiments is shown in Tab. 2. The calibration of the measurement device was made.

Table 2 the Measurement Device Used For TAFPM-NN Type Motor Experiment Setup

\begin{tabular}{|l|l|}
\hline \multicolumn{1}{|c|}{ The Purpose } & \multicolumn{1}{|c|}{ The Measurement Device } \\
\hline $\begin{array}{l}\text { To drive TAFPMOS-NN type } \\
\text { motor }\end{array}$ & ACS 800 series driver \\
\hline $\begin{array}{l}\text { To measure load-torque } \\
\text { experiment }\end{array}$ & NCTE 2000 torque sensor \\
\hline $\begin{array}{l}\text { To sample and record } \\
\text { receiving data }\end{array}$ & Personal DAQ view card \\
\hline $\begin{array}{l}\text { To Obtain the torques of } \\
\text { cogging torque and standby } \\
\text { mode }\end{array}$ & Torque sensor \\
\hline $\begin{array}{l}\text { To define and observe the } \\
\text { waveform of voltage and } \\
\text { current and cos } \theta\end{array}$ & Fluke oscillascop 199C \\
\hline To Analyze power flow & Fluke 434 power analyzer \\
\hline $\begin{array}{l}\text { To Measure rms value of } \\
\text { voltage and current }\end{array}$ & Fluke 189 multimeter \\
\hline
\end{tabular}

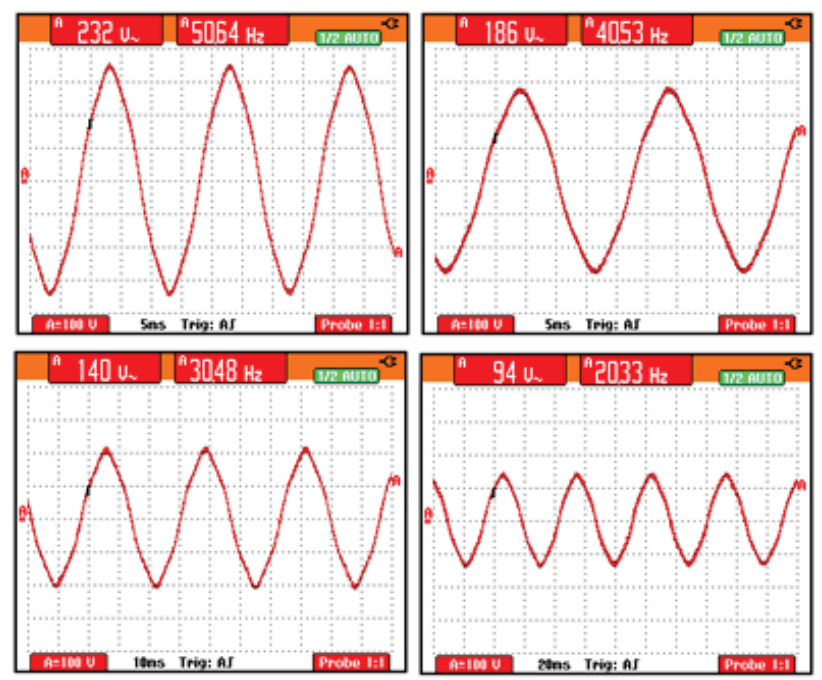

Figure 9 The Frequency-Voltage Values of TAFPMOS-NN Type Motor [21]

The waveforms of TAFPMOS-NN motor in different frequency are shown in Fig. 9. In this design, although the rectangular permanent magnet was used, the precision sinusoidal was obtained in the out of TAFPMOS-NN motor by providing configuration of permanent magnet and winding. In the former study, the harmonic distortion of sinusoidal less than $3,5 \%$ in total is measured [21].

Table 3 The Electrical Parameters of TAFPM-NN Type Motor in $50 \mathrm{~Hz}$

\begin{tabular}{|c|c|c|c|c|c|c|c|}
\hline $\begin{array}{c}\text { Torque } \\
(\mathrm{N} \cdot \mathrm{m})\end{array}$ & $\begin{array}{c}\text { Output } \\
\text { Power } \\
(\mathrm{W})\end{array}$ & $\begin{array}{c}U_{\mathrm{h}} \\
(\mathrm{V})\end{array}$ & $\begin{array}{c}I_{\mathrm{h}} \\
(\mathrm{A})\end{array}$ & $\begin{array}{c}\text { Input } \\
\text { Power } \\
(\mathrm{W})\end{array}$ & $\begin{array}{c}\text { Sinput } \\
(\mathrm{VA})\end{array}$ & $\operatorname{Cos}(\theta)$ & $\begin{array}{c}\text { Efficiency } \\
(\%)\end{array}$ \\
\hline 24 & 1076 & 255 & 24 & 1201 & 1213 & 0,990 & 0,896 \\
\hline 32 & 1435 & 260 & 32 & 1638 & 1655 & 0,990 & 0,875 \\
\hline 40 & 1794 & 265 & 40 & 2123 & 2131 & 0,996 & 0,845 \\
\hline 48 & 2153 & 270 & 48 & 2604 & 2639 & 0,987 & 0,826 \\
\hline 56 & 2512 & 285 & 56 & 3093 & 3106 & 0,996 & 0,811 \\
\hline 64 & 2870 & 280 & 64 & 3795 & 3765 & 0,994 & 0,762 \\
\hline 72 & 3229 & 270 & 72 & 4605 & 4605 & 0,994 & 0,701 \\
\hline
\end{tabular}

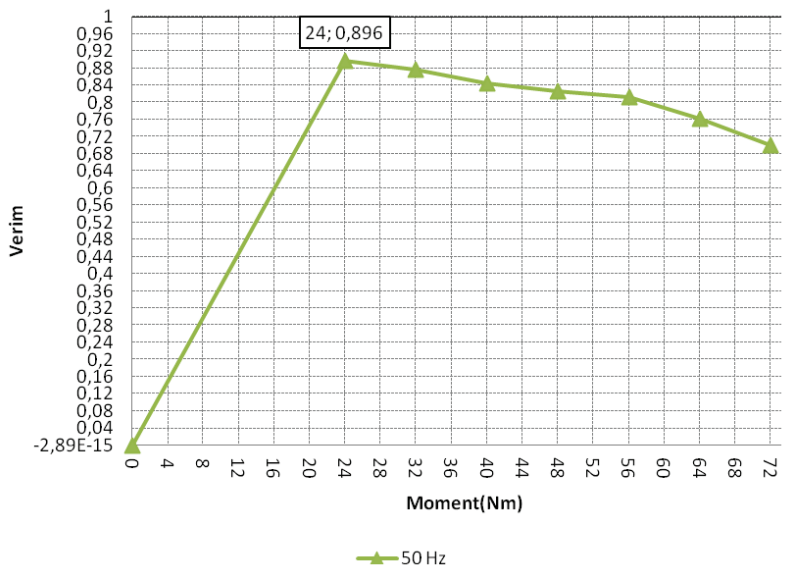

Figure 10 The Torque-Efficiency Values of TAFPMOS-NN Type Motor in $50 \mathrm{~Hz}$ [21]

TAFPMOS-NN type motor is driven different voltage levels of the source in $50 \mathrm{~Hz}$, the obtained electrical parameters from the different voltage levels were given in Tab. 3. Though new design has big air gap values, the efficiency of TAFPMOS-NN type motor was calculated $89,6 \%$ with a $1201 \mathrm{~W}$ input power.

The efficiency torque graph of TAFPMOS-NN type motor is given in Fig. 10. The designed TAFPMOS-NN type motor for the efficiency band $80 \div 90 \%$ is able to work between $24 \div 56 \mathrm{~N} \cdot \mathrm{m}$ torque values.

\section{Conclusion}

The most important property of the axial flux permanent magnet type motors without the core is absence of cogging torque. Therefore, the researches on the open-slotted machine are at an advanced level. In addition, because the axial flux permanent magnet coreless type motors have low power density and are not suitable for high power demanding applications. But the open-slotted machines have some problems such as cogging torque.

This paper presents a new hybrid structure TAFPMOS-NN type motor. The main feature of TAFPMOS-NN type motor is the increased air gap of TAFPMOS-NN type motor so the cogging torque is decreased. But, increasing the air gap leads to the performance losses. The performance losses in axial flux permanent magnet type motors without the core are decreased by changing configuration of the winding.

TAFPMOS-NN type motors in comparison with the same type motors have more windings, and the external cooling system design for TAFPMOS-NN type motors may be provided obtaining high torque. Because the torque density increases, the efficiency of TAFPMOS-NN type motors increases. The high torque density for this type machines is a very important fact.

The designed TAFPMOS-NN type motor in terms of obtained results is the ideal choice for the motor having direct-drive, high power density and low cogging torque. Besides, the open-slotted and rectangular permanent magnet structures provide cost-reduction. In the future studies, the open-slotted machines design could be used for production of electricity in winding turbine and highspeed applications. 
Except of the above results, the designed TAFPMOSNN type motor for operating alternator mode is able to have lower harmonic by changing step and distributing coefficient in the structure of wound windings. At the same time, a useful structure for electrical vehicle can be obtained by developing of designed model. Also ideal direct-drive motor with open-slotted structure axial flux and providing more efficiency at high frequency in this design may be acquired for electric vehicle by using soft magnetic composites.

This study reveals that serious research on axial flux machines with open-slotted structure needs to be done. Moreover axial flux machines provide high power density and high starting torque; with their compact structure the axial flux machine can be used in many areas and is accepted as important machine.

\section{Acknowledgements}

This work was supported by the Scientific Research Project Program of Marmara University (Project No: FEN-E-080415-0112).

\section{Acronyms}

TAFPMOS-NN - Toroidal Axial Flux Permanent Magnet Open Slotted North to North

NN - North to North

EMF - Electro Motor Force

TAFPM - Toroidal Axial Flux Permanent Magnet TAFPM-NN - Toroidal Axial Flux Permanent Magnet North to North

DAQ - Data Acquisition Card.

\section{References}

[1] Mahmoudi, A.; Ping, H. W.; Rahim, N. A. Comparison between the Torus and AFIR Axial-Flux PermanentMagnet Machine Using Finite Element Analysis. // IEEE International Electric Machines \& Drives Conference (IEMDC), 2011.

[2] Park, J. C.; Choi, H. R.; Choe, G. H. A Study on AFPM (Axial Flux Permanent Magnet) Motor without Stator Core. // Power Electronics Specialists Conference PESC'06, P.16, 2006. DOI: 10.1109/PESC.2006.1711737

[3] Crescimbini, F.; Napoli, A. D.; Solero, L.; Caricchi F. Compact Permanent Magnet Generator for Hybrid Vehicle Applications. // IEEE Transactions on Industry Applications, Vol. 41, No. 5, September, 2005. DOl: 10.1109/TIA.2005.855048

[4] Fei, W.; Luk, P. C. K.; Jinupun, K. A New Axial Flux Permanent Magnet Segmented-Armature-Torus Machine for In Wheel Direct Drive Application. // IEEE, 2008.

[5] Aydin, M.; Huang, S.; Lipo, T. A. A New Axial Flux Surface Mounted Permanent Magnet Machine Capable of Field Control. // IEEE, 2002. DOI: 10.1109/ias.2002.1042719

[6] Espanet, C.; Tekin, M.; Bernard, R.; Miraoui, A.; Kauffmann, J. M. A New Structure of an High Torque InWheel Motor. // Electrical Machines and Systems Sixth Internaitonal Conference ICEMS. 1, (2003), pp. 158-162.

[7] Parviainen, A.; Niemela, M; Pyrhönen, J. A Novel Axial Flux Permanent Magnet Machine to Laboratory Use. // International Symposium on Electromagnetic Fields in Electrical Engineering ISEF, Maribor, Slovenia, September 18-20, 2003, pp. 277-280. DOI: 10.1007/1-4020-3169-6_58
[8] Zaher, R. A.; Groot, S.; Polinder, H.; Wieringa, P. Comparison of an axial flux and a radial flux permanent magnet motor for solar race cars. // Conference on Electrical Machines - ICEM, Rome, 2010.

[9] Caricchi, F.; Capponi, F. G.; Crescimbini, F.; Solero, L. Experimental Study on Reducing Cogging Torque and NoLoad Power Loss in Axial Flux Permanent Magnet Machines With Slotted Winding. // IEEE Transactions on Industry Applications. 40, 4(2004), pp. 1066-1075. DOI: 10.1109/TIA.2004.831273

[10] Aydin, M.; Zhu, Z. Q.; Lipo, T. A.; Howe, D. Minimization of Cogging Torque in Axial Flux Permanent Magnet Machines: Design Concepts. // IEEE Transactions on Magnetics. 43, 9(2007), pp. 3614-3622. DOI: 10.1109/TMAG.2007.902818

[11] Parviainen, A.; Pyrhönen, J.; Niemela, M. Axial Flux Interior Permanent Magnet Sychronous Motor With Sinusoidally Shaped Magnets. // $10^{\text {th }}$ International Symposium on Electromagnetic Fields in Electrical Engineering ISEF, Cracow, Poland, September 20-22, 2001.

[12] Marignetti, F.; Colli, V. D.; Cancelliere, P.; Scarano, M.; Boldea, I.; Topor, M. A Fractional Slot Axial Flux PM Direct Drive. // Electric Machines and Drives IEEE International Conference. May, 2005. pp. 689-695.

[13] Rahim, N. A.; Ping, H. W.; Tadjuddin, M. Design of Axial Flux Permanent Magnet Brushless DC Motor for Direct Drive of Electric Vehicle. // IEEE Power Engineering Society General Meeting, 24-28 June, 2007.

[14] Choi, J. H.; Kim, J. H.; Kim, D. H.; Baek, Y. S. Design and Parametric Analysis of Axial Flux PM Motors With Minimized Cogging Torque. // IEEE Transactions on Magnetics. 45, 6(2009), pp. 2855-2858. DOl: 10.1109/TMAG.2009.2018696

[15] Hsu, J. S. A Machine Approach for Field Weakening of Permanent Magnet Motors, Society of Automotive Engineers, 1998.

[16] Tapia, J. A.; Gonzalez, D.; Wallace, R. R.; Valenzuela, M. A. Axial Flux Surface Mounted PM Machine with Field Weakening Capability. // Springer Recent Developments of Electrical Drives, (2006), pp 321-334. DOI: 10.1007/978-14020-4535-6_27

[17] Gonzalez-Lopez, D. A.; Tapia, J. A.; Wallace, R.; Valenzuela, A. Design and Test of an Axial Flux Permanent Magnet Machine with Field Control Capability. // IEEE Transactions on Magnetics. 44, 9(2008), pp. 2168-2173. DOI: 10.1109/TMAG.2008.2000543

[18] Profumo, F.; Tenconi, A.; Zhang, Z.; Cavagnino, A. Novel Axial Flux Interior PM Synchronous Motor Realized with Powdered Soft Magnetic Materials. // IEEE Industry Applications Conference. 1, (1998), pp. 152-158. DOI: 10.1109/ias.1998.732275

[19] Huner, E.; Akuner, M. C. Axial-Flux Synchronous Machines Compared with Different Stator Structures for Use in Working. // Prezeglad Elektrotechniczny, 2012.

[20] Akuner, M. C.; Huner, E. Theoretical and Experimental analysis of Open-Slotted Axial-Flux Permanent Magnet Electrical Machine. // Energy Education Science and Technology Part A: Energy Science and Research. 29, 2(2012), pp. 2217-2226.

[21] Huner, E. Toroidal Winding Open Slotted Axial Flux Permanent Magnet NN Type Motor Design and Application. // Ph.D. Thesis, 2012.

[22] Gieras, J. F.; Gieras, I. A. Performance Analysis of a Coreless Permanent Magnet Brushless Motor. // IEEE Industry Applicaitons Conference. 4, (2002), pp. 24772482. DOI: 10.1109/ias.2002.1042794

[23] Sadeghierad, M.; Lesani, H.; Mosef, H.; Darabi, A. Air Gap Optimization of High-Speed Axial Flux PM Generator. // 
Journal of Applied Sciences. 34, 1/2(2009), pp. 1915-1921.

DOI: 10.3923/jas.2009.1915.1921

[24] Huner, E.; Akuner, C. Open Slotted Stator with Multilayer Windings. // Useful Model, 2012/09784, 21.03.2014.

\section{Authors' addresses}

\section{Engin Hüner}

Kırklareli Üniversitesi

Teknoloji Fakültesi

Enerji Sistemleri Mühendisliği Bölümü

Kayalı Yerleşkesi-Kirklareli, Turkey

E-mail: enginhuner80@hotmail.com

\section{Mustafa Caner Akuner}

Department of Mechatronic Engineering,

Technology Faculty Marmara University,

Istanbul, Turkey 34722.

E-mail: akuner@marmara.edu.tr

\section{Ŭ̌ur Demir}

Department of Mechatronic Engineering,

Yildiz Technical University, Istanbul, Turkey

E-mail: ugur-demir@outlook.com 